\title{
Understanding Students' Learning Strategies as an Input Context to Design English Classroom Activities
}

\author{
Karim Mattarima (Corresponding author) \\ Faculty of Education, Universiti Teknologi Malaysia \\ UTM Skudai, Johor Bahru, Johor Darul Ta'zim, 81310, Malaysia \\ Tel: 60-1-0884-0410 E-mail: karimmattarima@yahoo.co.id
}

\author{
Abdul Rahim Hamdan \\ Faculty of Education, Universiti Teknologi Malaysia \\ UTM Skudai, Johor Bahru, Johor Darul Ta'zim, 81310, Malaysia \\ Tel: 60-1-2788-0166 E-mail: p-rahim@utm.my
}

Received: June 30, 2011 Accepted: August 4, $2011 \quad$ Published: December 1, 2011

doi:10.5539/ijps.v3n2p238 URL: http://dx.doi.org/10.5539/ijps.v3n2p238

\begin{abstract}
Learners' individual differences in learning English as a foreign language with large-mixed ability classes needs a great attention in increasing their communicative language skills. One of Learners' differences is learning strategies. Learning strategy has a great role to promote students' autonomy. It is one of front liners in developing communicative skills of English. Understanding students' learning strategies becomes a strategic and important issue to gain brilliant ideas to design classroom activities and then, to promote students' autonomy. The study conducted with students in two senior high schools, SMA Negeri 15 and SMA Negeri 16 Makassar South Sulawesi Province, Indonesia found that students only used meta-cognitive strategies at a high frequency and memory, cognitive, compensation, affective, and social strategies at a medium frequency. In meta-cognitive strategies, students have several degrees of autonomy promotion by independently organizing and evaluating their learning progress, although other five learning strategies need intensively great efforts to support their autonomy. Further implications of the study in English foreign language teaching and learning in the context of implementing school based curriculum in Indonesia are also discussed.
\end{abstract}

Keywords: Learners' differences, Learning autonomy, Learning strategies, English foreign language, Classroom activities

\section{Introduction}

Shift in teaching and learning process from teacher-centered to learner-centered needs more various pro-student approaches. The approaches focus on students' learning activities. In doing their activities, students apply different efforts because of having different individual potencies. From these individual differences, they also learn in different ways. Understanding individual differences of students such as motivation, learning strategies, attitudes, and learning styles is necessary for teachers to set appropriate instructions. Students' differences in learning challenge teachers to prepare and apply various instructions with the same materials in order to gain learning objectives for all students. Teachers should have skills in classroom instruction for all students and in individualized instruction for each student.

Focus of this study is on understanding learning strategies as a front line in learner-centered approaches in teaching and learning English as a foreign language. The great reason as the background of doing this study is to maximize the implementation of school based curriculum of English in large class with mixed-ability learners. Large class with mixed-ability of English language in the context of teaching English as foreign language makes the greatest challenge for language teachers to have maximal and dynamic efforts to improve students' communicative skills. Understanding students' learning strategies possibly contributes teachers' dynamic and interesting efforts to where conditions they apply classroom instruction or individualized instruction in teaching and learning process. These efforts would become practical guidelines to carry out students' learning activities, and then intensively promote and develop students' learning autonomy. 


\section{Literature Review}

\subsection{Issues of Learner Centered Instruction}

Instruction refers to methods of teaching and the learning process used to help students practice their skills about the curriculum content and objectives specified and reach the standards have been arranged (Pellegrino, 2004). Instruction, as stated by Dijkstra (2004), is the communicative interaction between a student and a teacher and instructional design is a set of rules to design and develop the verbally and written communicative interaction. It means that instruction focuses on the interaction methods of both teachers and students and can be run by a variety of activities, sequences of tasks, and topic orders to be practice.

Giving appropriate instruction in the classroom is necessary to develop teaching and learning process. From the part of teacher, teaching may be effective accepted and from part of students, learning may be more effective process to gain the maximum progress based on learning objectives because an appropriate instruction is applied in the classroom. Willis (2009) stated that the rapid progress of students and the high standard of attainment can be reached by giving the appropriate instruction in learning.

One of useful instruction to involve greatly students and to have great potency to gain the rapid and meaningful progress and high attainment of students in teaching and learning process is learning-center approach. Learning-centered approach is an approach in which each student is more involved in learning process. Weimer (2002) stated that learning-centered teaching is a teaching approach in which students have more controlled over their learning. With the learner-centered approach, teachers more involved as facilitators of facilitating learning rather than teachers of teaching. In this way, teachers do less talking and explaining but students do more discovering their understanding. Weimer further claimed that the roles of teacher in the learner-centered approach are to design the course, to create an optimal learning climate, to promote students with the appropriate and expected behavior, to motivate students to learn, and to provide constructive feedback at the process.

Brown (2001) stated that learner-centered applies to curricula as well as to specific techniques. It is different from teacher-centered, and has received various recent interpretations. Learner-centered instruction includes:

a. Techniques that focus on or account for learners' needs, styles, and goals.

b. Techniques that give control to the student (group work or strategy training, for example).

c. Curricula that include the consultation and input of students and that do not presuppose objectives in advance.

d. Techniques that enhance a student's sense of competence and self-worth.

In this way, Kai I Cheang and PharmD (2009) stated that the learner-centered instruction gives students more optional chances and allows them to serve their own learning needs. Teaching and learning content is still introduced and utilized but in a more individual way. Application of the teaching content is also emphasized and used to develop critical-thinking skills. Learner-centered teaching forces students to play an active role in their classroom, as opposed to the more passive traditionally used.

Teachers in Indonesia are still occupying teacher-centered approach and rote learning as the instructional method (Zulfikar, 2009). The situation has to be a focus to shift to learner-centered approach because from those specialists, learner-centered approach is very crucial when students' involvement in teaching learning process needs to be maximized in their own ways. To be effective in teaching and learning process with students' involvement in their own ways, understanding their individual differences is a need. Attitudes, motivation and learning strategies that are individual differences potentially appear among students in the classroom. Well understanding those individual differences will possibly more improve the effective teaching and learning process. Because of understanding the students' differences in learning like age, gender, attitudes, motivation, and strategies, differential treatment could be applied as equality effort for each student (Nation \& Macalister, 2010).

From those specialists, learner-centered approach is very crucial when students' involvement in teaching learning process needs to be maximized in their own ways. To be effective in teaching and learning process with students' involvement in their own ways, understanding their individual differences is a need. Motivation and learning strategies are two potential differences among students in the classroom. Well understanding two potential differences will possibly more improve the effective teaching and learning process.

\subsection{Learner Autonomy}

Deci and Ryan (2000) in self-determination theory (SDT) maintain that an understanding of human motivation requires a consideration of innate psychological needs for competence, autonomy, and relatedness. The theory emphasizes that needs specify the necessary conditions for psychological growth, integrity, and well-being. One 
of specific need, which is focused on this theory, is autonomy and it is one consideration of innate psychology in doing something especially in learning or acquiring a foreign language.

The word "autonomy" has several meanings based on where contexts it is used. If autonomy used in learning context, it means independent learning of students. Although students have to be independence, it doesn't mean they are isolated or without direction from other people such as teachers. Stevens (2007) revealed that autonomous does not mean isolated or by oneself' - an autonomous learner is one who self-starts him/herself in the direction of a learning strategy in which, these days, a learning community might figure highly.

Autonomy in learning is necessary. Autonomy or independent learning is one of criteria of successful learners. Autonomy is one of principles of language teaching and learning (Nation \& Macalister, 2010). Students who are independent or autonomous in learning have the greatest potency to be successful learners. Independent learners have strongly powerful efforts to inquire what is learnt, how is learnt, and why is learnt according to the syllabi's headlines. They will need few helps from their teachers. They are not learnt but they are mostly guided to learn. They mostly learn in their own strategies and styles. Students, who were independent, according to Van, R. J. and R. G. Abraham (1990) and Naimie, Z. and A. Naimie (2007), have great potency in appropriately selecting their learning strategies.

Egel (2009) stated that teachers should become agents on developing students' autonomy in the classroom context. Becoming agents is not an easy job for teachers. Teachers should understand their students' background, students' culture, students' need, students' motivation, and other individual characteristics. Griffiths (2009) also stated that characteristics of good language learners can give the greatest potential for change in relating to a student's use of language learning strategies. So teaching will help students to become better language learners.

Some characteristics of good language learners, according to Rubin and Thompson (1993), are follows:

1)Using the language at every available opportunity.

2) Practicing what they have just learnt as soon as possible.

3) Willing to try out different ways in order to get their message across.

4) Being able to overcoming their uncertainty and uneasiness.

5) Monitoring own speech as well as the speech of others.

6) Analyzing, categorizing and synthesizing new language.

7) Systematic organizing program and goals.

8) Applying different learning methods.

9) Understanding errors in working or learning.

10) Starting conversation or be initiator of conversation.

Furthermore, because of different learning characteristics, Hannell (2008) argued that learning outcome can be different. Some students are found learning very easy but some others are found learning difficultly and may comprise special needs. Their individual characteristics (like curious or apathetic, persistent or easily defeated, overly cautious or willing to take sensible risks and so on) will create the independence in learning. The level of independence would create significant difference to the quality of their learning. Teacher roles cannot be avoided to create interesting sustainability in teaching and learning process although the independence of students tends to be focused.

In order to help maximizing students' autonomy in learning, it is necessary for teachers to early know their students' individual differences, and then choose the appropriate classroom instruction and appropriate individual instruction. One individual difference of each student, language learning strategies, should be understood in promoting students' autonomy in learning.

In teaching and learning process, a teacher is one of great determiners to create independent learners in the classroom. A teacher has many other potential roles (a facilitator, a teammate, and a controller) to involve students independently. To ensure a high teacher-specific motivation of the students, according to Jinping (2005), a teacher should make great effort to be more sensitive to students needs, feelings, have a non-mental and positive regard to each student, and understand them as complex human being with both virtues and faults. A teacher is a facilitator rather than an authority figure in developing a warm rapport with the students to deduce their anxiety. A teacher should promote learner autonomy or independent learner by acknowledging different ways to goal attainment and learning styles, minimizing external pressure and control and fostering an intrinsic motivation, and sharing responsibility with the students in the learning process. Evidence shows that foreign 
language motivation and learner autonomy go hand in hand and autonomous language learners are generally motivated learners; and to promote learner curiosity by using varieties of teaching methods and activities.

Hannell (2008) expressed that teachers have to know the amazing diversity and variety of the individual learner which are reflected in every classroom they teach. Teachers should reduce to believe that all their students had the same view, same behavior, and the same style or way of learning. The best teachers have to work effectively with diversity, variety and differences of their students. Griffiths (2009) stated that teaching process would help, lead, and place students to become independent and better language learners.

\subsection{Language Learning Strategies}

Many researchers have defined the term language learning strategy. Faerch Claus and Casper (1983) stressed that learning strategy is "an attempt to develop linguistic and sociolinguistic competence in the target language." Wenden and Rubin (1987) define learning strategies as "... any sets of operations, steps, plans, routines used by the learner to facilitate the obtaining, storage, retrieval, and use of information." Richards at. al. (1992) state that learning strategies are "intentional behavior and thoughts used by learners during learning so as to better help them understand, learn, or remember new information." According to Stern (1992), "the concept of learning strategy depends on the assumption that learners consciously engage in activities to achieve certain goals and learning strategies can be regarded as broadly conceived intentional directions and learning techniques." Either consciously or unconsciously, language learning strategies are employed when language learners are processing new information and performing tasks in the language classroom. Since teaching and learning activity is like a problem-solving process, using language learning strategies is inescapable for students to find the quickest or easiest way to do new input and difficult tasks given by their instructors.

According to Rubin's classification (1987), there are three types of strategies used by learners that contribute directly or indirectly to language learning. They are learning strategies, communication strategies, and social strategies. Oxford (1990) divided language learning strategies into two main classes, direct and indirect, which are further subdivided into 6 groups. Oxford's direct strategies are memory, cognitive and compensation and indirect strategies are meta-cognitive strategies, affective strategies, and social strategies. Language learning strategies are classified by O'Malley et al. (1985) into meta-cognitive, cognitive, and socio-affective strategies. The three experts viewed learning strategies on the similar classification although Oxford's classification is superior in accounting for the variety of strategies used by language learners (Chamot, 2004). Based on the reason, this study employs Oxford's classification to the student's use of strategies.

Those taxonomies of strategies of language learning show the seriousness of scholars to view the importance of strategies in language learning. Factually, those taxonomies have the same purposes. They require helping students to succeed in learning language. Varieties of those taxonomies aim to make easiness to view learners from any potential aspects of teaching and learning such as the appropriateness between learners and materials, learners and teaching methods, and learners and teachers. From the differences of the individual learner to view the appropriateness, the learners have greater potency to succeed because they would use their own appropriate strategies in learning. It means that each learner has potency to differ in learning and potency to apply different strategies. Applying different strategies in learning a language is inevitable although they learn in the same classroom. Because of the reason, understanding learners' strategies in learning language requires to design classroom activities in syllabus and lesson plan to accommodate learners' easiness in learning.

Some previous studies investigated the link between learning strategies and learning autonomy. Mlstar (2001) argues that the link between learning strategies and learner autonomy is very close so that one can judge how autonomous F2/FL learners are from the strategies they employ in learning. With regard to the Indonesian learners of English, particularly those learning English at tertiary education levels, in order to increase their autonomy in learning, the learners still need more training in the use of memory, cognitive, compensation, and affective strategies. Mlstar's study found that the learners performed meta-cognitive and social strategies at a high range suggests that they have exercised autonomy in their learning activities. This assertion is made as the use of meta-cognitive strategies require the learners to independently organize and evaluate their learning activities and the use of social strategies require them to actively and independently involve themselves in communication activities using the target language.

In different context, Kato (2005) has some suggestions to do this kind of research. First, long-term research ideally from high school to university should be conducted to see how variables such as gender term of the learning, background, attitude, or motivation influence a student's choice of strategy. Second, more research is required regarding how students from different cultural backgrounds and countries utilize different strategies and prioritize common strategies differently. Third, more research should be developed to establish whether strategy 
use has a positive effect on the enhancement of proficiency. Finally, more research focused on the strategies used by Japanese university students needs to be undertaken, with the ultimate goal of improving their English proficiency. Kato recommends that teachers can help students recognize the power of using SILL for making learning quicker, easier, and more effective. Teachers can help students identify their current SILL by surveys or by other means. Sharing research results like those in this study is a good way to persuade students to use such strategies as much as possible when they study.

Furthermore, Ganjooei and Rahimi's study (2008) investigated whether language learning strategy use can predict the proficiency level of the learners and the other way round. Two hundred (200) Iranian undergraduate EFL learners arranged in two groups participated in this study. The first group of 100 learners was selected from Shiraz Virtual University who were exposed to an e-learning program, and the second one was a 100-learner group going through a traditional course studying at Shiraz University. This study was also conducted with Oxford's SILL. Their finding indicated that the type of education system has no contribution to language learning strategy use. No significant differences were observed with respect to the frequency with which the learners use each strategy type. It was also revealed that the effective use of strategies and the way learners usually go about learning is highly influenced by their level of proficiency in both groups. Finally, it was found that the use of learning strategies is predictable by learners' level of proficiency and the other way round.

\section{Research Objectives}

This study investigated learning strategies of senior high schools' students in learning English at Makassar, Indonesia. Objectives of the study were to find out the more frequently use of students' strategies in learning English and to find out more frequently use of activities in each category of strategies in learning English as a foreign language in senior high schools in Makassar, Indonesia.

\section{Research Questions}

The research questions formulated in this study were:

1) What strategies are more frequently used in learning English?

2) What activities are more frequently used in each category of strategies in learning English?

3) What are the implications of more frequently students' use of strategies in learning English in the implementation of school based curriculum?

\section{Methodology}

\subsection{Population and Sample}

The population in this study was senior high schools' students in XI grade of natural and social program in academic year 2010/2011. From the accessible population (170 students), 56 senior high schools' students from SMA Negeri 15 Makassar and SMA Negeri 16 Makassar were randomly selected as the sample. The reason for selecting XI grade students was that X grade students are still new and XII grade students are prepared to face National or Final Examination.

\subsection{Procedures and Instrumentation}

Before distributing the questionnaire in collecting data, the SILL (Strategy Inventory for Language Learning) as developed by Oxford (1990) still needs to be validated because it would be used in different context of environment, culture, and education system although the SILL has good reliability and validity (Teh, et al., 2009). The SILL questionnaire was translated into Indonesian language by using back to back translation. The result of translation was verified by Center of Language Service (CLS) of State University of Makassar and then validated by two lecturers from the same university, one English language teaching lecturer and one psychology lecture. By study piloting, it was found alpha value is 0.95 for all and 0.88 for memory, 0.85 for cognitive, 0.89 for compensation, 0.88 for metacognitive, 0.90 for social and 0.88 for affective. The SILL has 50 items to assess 6 categories with 5 point likert-scales, from 'always true' to 'never true'. Those items were included in the result of the study.

The SILL questionnaire was administered in Indonesian language in order to make students really understand each item of the questionnaire. They completed it in one learning session classroom after given previous explanation of the way to answer it and of confidential students' answers. They also were informed to answer it carefully and allowed to ask if they found difficulties. The six categories investigated were memory with nine items, cognitive with fourteen items, compensation with six items, metacognitive with nine items, social with six items, and affective with six items. The six categories were analyzed in statistical procedure by accumulating 
students' responses in three levels, high if mean is 3.50-5.00, medium if mean is $2.50-3.49$, and low if mean is 1.00-1.49 (Oxford, 1990).

\section{Findings}

To analyze the students' responses to the questionnaire, this study used descriptive analysis Mean of the data was calculated by using the Statistical Package for Social Sciences (SPSS) 16 software.

Based on data analysis in memory strategies, only item 8 "reviewing English lessons often" was used in high frequency, only item 6 'using flashcards to remember new English words' was used in low frequency, and others was used in medium frequency. It means that respondents usually or always review their English lessons but they almost never or never use flashcards to remember new English words. Table 1 completely shows the frequency and category of each strategy in memory strategies.

From fourteen cognitive strategies, item 10,11, and 12, and 15 were used in high frequency, no item was in low frequency, and other items were in medium frequency. It means that respondents usually or always say or write new English words several times, try to talk like native English speakers, practice the sounds of English, and watch TV with English language programs, as shown in table 2.

The use of compensation strategies with assessed by six items shows five items in medium frequency and only one item in high frequency. Respondents responded that they always or usually use a word or phrase which the same thing if they can't think of an English word. Table 3 shows mean and category of each strategy in compensation strategies.

In meta-cognitive strategies with eight items, items with high frequency are more than ones with medium frequency. Table 4 clearly shows mean and category of each item.

Four items $(39,40,41$, and 42) with high frequency and two others with medium frequency (43 and 44) are clearly shown in table 5. Respondents had high frequency in trying to relax whenever they felt afraid of using English, in encouraging their selves to speak English even when they were afraid of making a mistake, in giving their selves a reward or treat when they did well in English, and in noticing if they were tense or nervous when they were studying or using English.

With six items in social strategies, four items are in high frequency, two are in medium frequency, and no item is in low frequency. Table 6 clearly reveals the mean and the category of each strategy in social strategies.

In analyzing each domain of language learning strategies, it was found that five domains in medium frequency are memory, cognitive, compensation, affective, and social strategies, one domain in high frequency is meta-cognitive strategies, and on domain is in low frequency. Among five domains in medium frequency, the use of compensation strategies has the least frequency. The mean and the category of each domain in language learning strategies are clearly presented in table 7 .

\section{Discussion}

This study was carried out to find out the frequency of students' use of learning strategies and frequency of students' use of individual strategies in each domain of learning strategies of English, and to give recommendations deal with the findings of the study. This study found that students of senior high schools in Makassar, Indonesia had high frequency in using meta-cognitive strategies, medium frequency in using memory, cognitive, compensation, affective, and social strategies, and no strategies in low frequency. Among learning strategies in medium frequency, this study found that the use of compensation strategies had the least frequency.

These findings are slightly different from some previous studies (Mlstar, 2001; Kato, 2005; and Ganjooei and Rahimi, 2008). In the same area of study in Malang, Mlstar's (2001) study found that meta-cognitive and social strategies were in high frequency but he similarly found that the use of compensation strategies were the least frequency among strategies in medium frequency. Ganjooei and Rahimi (2008) similarly found that only the use of meta-cognitve had high frequency although they differently found that the use of affective strategies had the least frequency among six domains of language learning strategies.

In this study, individual strategies in each domain of language learning strategies were also found 19 individual strategies in high level of frequency. This study found fewer individual strategies in high frequency than Mlstar's findings (2001). Those individual strategies in this study are shown in table 8.

This study also reveals that the use of other 30 strategies (in medium and low frequency) still needs intensive efforts to maximize their frequency in learning English as a foreign language. 
In relation to implementation of school based curriculum, identifying and formulating English language teaching and learning, including identifying learning materials, selecting instruction and teaching media, teachers should be considered learners' potency, subject characteristics, district characteristics, and the usefulness to the learners. To decide learning activities, teachers should think various ways to actively involve each student in learning process. Teachers should focus on the steps of learning process to gain every communicative competence (KTSP SMA, 2006). To have great efforts, teachers do not only have teaching competence but they should also have knowledge about learners' individual potency, like learning strategies. Students' learning strategies are necessary to design learning activities in the classroom. Dornyei (2005) states an activity becomes strategic when it is particularly appropriate for the individual learner.

\section{Conclusion and Implication}

The study findings suggest a number of implications in English language teaching and learning process in the classroom and in the design of school based curriculum of English in senior high schools. Those implications are as follows:

1. In order to promote higher learning autonomy of students, teachers should continuously maintain the highly frequent use of students' learning strategies by inserting those strategies in designing syllabi, lesson plan, and classroom activities.

2. Teachers should have continuously hard and creative efforts in developing their instructional activities to encourage their students' participation by designing other dynamic and interesting activities, like developing their creativity in using the least frequency of such those individual strategies.

3. Teachers must search and understand the sources of high, medium, and even low frequency of using learning strategies to constructively contribute in developing learning materials, implement teaching techniques and media, and creating learning activities in teaching and learning English as a foreign language by further doing qualitative study.

The study concluded that students of senior high schools in Makassar were moderate in using all language learning strategies (as developed by Oxford, 1990), and tended to have high frequency in using meta-cognitive strategies and medium frequency in memory, cognitive, compensation, affective, and social strategies. Focus to understand students' learning strategies may lead teachers to promote students' autonomy in learning. So, it is a must for teachers to carefully understand their students' strategies before, whilst, and after learning process. Green, J. M. and R. Oxford (1995) stated that the more that teachers know about such factors, the more readily the teacher can come to grips with the nature of individual differences in the classroom. Such knowledge is power- the power to plan lessons so that students with many different characteristics, including varied strategies, can receive what they need.

With regard to the implementation of school based curriculum of English with learner-based approaches in Indonesian senior high schools, teachers still need to train their students in the use of memory, cognitive, compensation, social, and affective strategies in order to develop their autonomy in learning.

\section{Acknowledgements}

The deepest appreciation and unlimited thankfulness addressed to our family, our colleagues, and all staffs of Faculty of Education, Universiti Teknologi Malaysisa.

\section{References}

Brown, H.D. (2001). Principles of language learning and teaching. New Jersey: Prentice Hall Regents.

Chamot, A. U. (2004). Issues in Language Learning Strategy Research and Teaching. Electronic Journal of Foreign Language Teaching, 1(1): 14-26

Deci, E. L., \& Ryan, R. M. (2000). The "What" and "Why" of Goal Pursuits: Human Needs and the Self-Determination of Behavior. Psychological Inquiry, 11(4), 227-268. http://dx.doi.org/10.1207/S15327965PLI1104_01

Depdiknas (2006). Pedoman Kurikulum Tingkat Satuan Pendidikan 2006. Jakarta: Depdiknas.

Dijkstra, S. (2004). The Integration of Curriculum Design, Instructional Design, and Media Choice. In N. M.

Dornyei, Z. (2005). The Psychology of the Language Learner. Individual Differences in Second Language Acquisition. New Jersey: Lawrence Erlbaum Associates. 
Egel, I. P. (2009). Learner autonomy in the language classroom: from teacher dependency to learner independency. Procedia Social and Behavioral Sciences, 1: 2023-2026. http://dx.doi.org/10.1016/j.sbspro.2009.01.355

Faerch, C., \& Gabriele Kasper. (1983). Strategies in interlanguage communication. London : Longman.

Ganjooei, B. A., \& A. Rahimi.

(2008). Language Learning Strategy Use for EFL E-Learners and Traditional Learners: A Comparative Study. International Journal of Instructional Technology and Distance Learning, 5(12): 3-22

Green, J. M., \& R. Oxford. (1995). A Closer Look at Learning Strategies, L2 Proficiency, and Gender. TESOL QUARTERLY, 29(2), 261-297. http://dx.doi.org/10.2307/3587625

Griffiths, D. (2009). Second Language Acquisition. Pedagogic Grammar. Open Distance Learning, 1-33

Hannell, G. (2008). Success with Inclusion 1001 Teaching Strategies and Activities That Really Work. London: Routledge

Jinping, T. (2005). Classroom Language Teaching and Students Motivation. CELEA Journal, 28(2), 90-94

Kai I. Cheang \& PhamD, MS. (2009). Instructional Design and Assessment. Effect of learner-centered teaching on motivation and learning strategies in a third-year pharmacotherapy course. American Journal of Pharmaceutical Education, 73(3): 1-8

Kato, S. (2005). How Language Learning Strategies affect English Proficiency in Japanese University Students. Journal of Bunkyo Gakuin University, 7(1): 239-262

Mlstar, J. (2001). Maximing learning strategies to promote learner autonomy. TEFLIN Journal, 12(1): 1-10

Naimie, Z., \& Naimie, A. (2007). Field Dependent Students Language Learning Strategies Preference. Paper presented at the International Conference on Education.

Nation, I. S. P., \& Macalister, J. (2010). Language Curriculum Design. New York: Routledge.

OMalley, J.M., \& Anna Uhl Chamot. (1990). Learning strategies in second language acquisition. United Kingdom: Cambridge University Press.

Oxford, R.L. (1990). Language learning strategies: what every teacher should know. New York : Newbury House Publisher.

Pellegrino, J. W. (2004). Complex Learning Environments: Connecting Learning Theory, Instructional Design, and Technology. In N. M. Seel \& S. Dijkstra (Eds.), Curriculum, Plans, and Processes in Instructional Design. International Perspectives. New Jersey: Lawrence Erlbaum Associates.

Richards, J.C., \& Rogert (1992). Longman dictionary of language teaching and applied linguistics. United Kingdom : Longman Group.

Rubin, J., \& I. Thompson (1994). How to be a more successful language learner : toward learner autonomy. Boston, Mass., Heinle \& Heinle.

Seel \& S. Dijkstra (Eds.), Curriculum, Plans, and Processes in Instructional Design. International Perspectives (pp. 400). New Jersey: Lawrence Erlbaum Associates.

Stern, H.H. (1992). Issues and options in language teaching. Oxford : Oxford University Press.

Stevens, V. (2007). The Multiliterate Autonomous Learner: Teacher Attitudes and the Inculcation of Strategies for Lifelong Learning. IATEFL: 27-29

Teh, K. S. M., Embi, M. A., Yusoff, N. M. R. N., \& Mahamod, Z. (2009). Language Learning Strategies and Motivation among Religious Secondary School Students. The International Journal of Language Society and Culture, (29), 71-79

Van, R. J., \& Abraham, R. G. (1990). Strategies of Unsuccessful Language Learners. TESOL QUARTERLY, 24(2), 177-198. http://dx.doi.org/10.2307/3586898

Weimer, M. (2002). Learning-Centered Teaching: Five Key Changes to Practice. San Fransisco, CA: Jossey-Bass.

Wenden, A \& John Rubin. (1987). Learner strategies in language learning. New Jersey: Prentice-Hall.

Willis, D. (2009). Rules, Patterns and Words. Grammar and Lexis in English Language Teaching. New York: Cambridge University Press. 
Zulfikar, T. (2009). The Making of Indonesian Education: An Overview on Empowering Indonesian Teachers. Journal of Indonesian Social Sciences and Humanities, 2, 13-39

Table 1. Mean frequencies of memory strategies

\begin{tabular}{|c|c|c|c|}
\hline No. & Strategy & Mean & Category \\
\hline 1 & $\begin{array}{l}\text { I think of relationships between what I already know and new } \\
\text { things I learn in EFL teaching. }\end{array}$ & 3.39 & Medium \\
\hline 2 & I use new English words in a sentence so I can remember them. & 3.39 & Medium \\
\hline 3 & $\begin{array}{l}\text { I connect the sound of a new English word and an image or } \\
\text { picture of the word to help me remember the word. }\end{array}$ & 3.50 & Medium \\
\hline 4 & $\begin{array}{l}\text { I remember a new English word by making a mental picture of a } \\
\text { situation in which the word might be used. }\end{array}$ & 3.03 & Medium \\
\hline 5 & I use rhymes to remember new English words. & 3.10 & Medium \\
\hline 6 & I use flashcards to remember new English words. & 2.44 & Low \\
\hline 7 & I physically act out new English words. & 2.82 & Medium \\
\hline 8 & I review English lessons often. & 3.71 & High \\
\hline 9 & $\begin{array}{l}\text { I remember new English words or phrases by remembering their } \\
\text { book pages, blackboard, traffic symbols or others. }\end{array}$ & 3.16 & Medium \\
\hline
\end{tabular}

Table 2. Mean frequencies of cognitive strategies

\begin{tabular}{|c|c|c|c|}
\hline No. & Strategy & Mean & Category \\
\hline 10 & I say or write new English words several times. & 3.52 & High \\
\hline 11 & I try to talk like native English speakers. & 3.66 & High \\
\hline 12 & I practice the sounds of English. & 4.00 & High \\
\hline 13 & I use English words I know in different ways. & 3.44 & Medium \\
\hline 14 & I start conversations in English. & 2.89 & Medium \\
\hline 15 & $\begin{array}{l}\text { I watch English language TV shows spoken in English or go to } \\
\text { movies spoken in English. }\end{array}$ & 3.57 & High \\
\hline 16 & I read for pleasure in English. & 3.00 & Medium \\
\hline 17 & I write notes, messages, letters, or reports in English. & 2.66 & Medium \\
\hline 18 & $\begin{array}{l}\text { I first skim an English passage (read over the passage quickly) } \\
\text { then go back and read carefully. }\end{array}$ & 3.09 & Medium \\
\hline 19 & $\begin{array}{l}\text { I look for words in my own language that are similar to new } \\
\text { words in English. }\end{array}$ & 3.25 & Medium \\
\hline 20 & I try to find patterns in English. & 3.16 & Medium \\
\hline 21 & $\begin{array}{l}\text { I find the meaning of an English word by dividing it into parts } \\
\text { that I understand. }\end{array}$ & 3.01 & Medium \\
\hline 22 & I try not to translate into English by word per word. & 2.76 & Medium \\
\hline 23 & I make summaries of information that I hear or read in English. & 2.85 & Medium \\
\hline
\end{tabular}

Table 3. Mean frequencies of compensation strategies

\begin{tabular}{|l|l|l|l|}
\hline No. & Strategy & Mean & Category \\
\hline 24 & To understand unfamiliar English words, I make guesses. & 3.08 & Medium \\
25 & $\begin{array}{l}\text { When I can't think of a word during a conversation in English, I } \\
\text { use gestures. }\end{array}$ & 3.05 & Medium \\
26 & I make up new words if I do not know the right ones in English. & 3.30 & Medium \\
27 & I read English without looking up every new word. & 2.60 & Medium \\
28 & I try to guess what the other person will say next in English. & 2.84 & Medium \\
29 & $\begin{array}{l}\text { If I can't think of an English word, I use a word or phrase that } \\
\text { means the same thing. }\end{array}$ & 3.50 & High \\
\hline
\end{tabular}


Table 4. Mean frequencies of meta-cognitive strategies

\begin{tabular}{|l|l|l|l|}
\hline No. & Strategy & Mean & Category \\
\hline 30 & I try to find as many ways as I can to use my English. & 3.60 & Medium \\
31 & I notice my English mistakes and use that information to help me & 4.14 & High \\
& do better. & 4.21 & High \\
32 & I pay attention when someone is speaking English. & 4.03 & High \\
33 & I try to find out how to be a better learner of English. & 2.87 & Medium \\
34 & I plan my schedule so I will have enough time to study English. & 3.39 & Medium \\
35 & I look for people I can talk to in English. & 2.93 & Medium \\
36 & I look for opportunities to read as much as possible in English. & 3.78 & High \\
37 & I have clear goals for improving my English skills. & 3.91 & High \\
38 & I think about my progress in learning English. &
\end{tabular}

Table 5. Mean frequencies of affective strategies

\begin{tabular}{|c|c|c|c|}
\hline No. & Strategy & Mean & Category \\
\hline 39 & I try to relax whenever I feel afraid of using English. & 3.91 & High \\
\hline 40 & $\begin{array}{l}\text { I encourage myself to speak English even when I am afraid of } \\
\text { making a mistake. }\end{array}$ & 3.94 & High \\
\hline 41 & I give myself a reward or treat when I do well in English. & 3.71 & High \\
\hline 42 & $\begin{array}{l}\text { I notice if I am tense or nervous when I am studying or using } \\
\text { English. }\end{array}$ & 3.55 & High \\
\hline 43 & I write down my feelings in a language learning dairy. & 2.51 & Medium \\
\hline 44 & $\begin{array}{l}\text { I talk to someone else about how I feel when I am learning } \\
\text { English. }\end{array}$ & 2.89 & Medium \\
\hline
\end{tabular}

Table 6. Mean frequencies of social strategies

\begin{tabular}{|l|l|l|l|}
\hline No. & Strategy & Mean & Category \\
\hline 45 & If I do not understand something in English, I ask the other & 3.85 & High \\
& person to slow down or say it again. & & \\
46 & I ask English speakers to correct me when I talk. & 3.51 & High \\
47 & I practice English with other students. & 3.50 & High \\
48 & I ask for help from English speakers. & 3.87 & High \\
49 & I ask questions in English. & 3.21 & Medium \\
50 & I try to learn about the culture of English speakers. & 2.93 & Medium \\
\hline
\end{tabular}

Table 7. Mean frequencies of using each strategy in language learning

\begin{tabular}{|l|l|l|l|}
\hline Strategy & Mean & $\begin{array}{l}\text { Standard } \\
\text { Deviation }\end{array}$ & Category \\
\hline Memory strategies & 3.18 & 0.71 & Medium \\
Cognitive strategies & 3.20 & 0.67 & Medium \\
Compensation strategies & 3.06 & 0.67 & Medium \\
Meta-cognitive strategies & 3.65 & 0.66 & High \\
Affective strategies & 3.42 & 0.63 & Medium \\
Social strategies & 3.48 & 0.61 & Medium \\
\hline
\end{tabular}


Table 8 . The highly mean frequencies of individual strategies in six domains of language learning strategies

\begin{tabular}{|c|c|c|}
\hline Strategy Domains & No & Individual strategy \\
\hline Memory strategies & 1 & Often Reviewing English lessons \\
\hline \multirow[t]{4}{*}{ Cognitive strategies } & 2 & Saying or writing new English words several times \\
\hline & 3 & Trying to talk like native English speakers \\
\hline & 4 & Practicing the sounds of English \\
\hline & 5 & $\begin{array}{l}\text { Watching English language TV shows spoken in English or go } \\
\text { to movies spoken in English }\end{array}$ \\
\hline Compensation strategies & 6 & $\begin{array}{l}\text { If being not able to think of an English word, using a word or } \\
\text { phrase that means the same thing or using synonyms. }\end{array}$ \\
\hline \multirow[t]{5}{*}{ Meta-cognitive strategies } & 7 & $\begin{array}{l}\text { Noticing English mistakes and using that information to help } \\
\text { doing better }\end{array}$ \\
\hline & 8 & Paying attention when speaking English \\
\hline & 9 & Trying to find out how to be a better learner of English \\
\hline & 10 & Having clear goals for improving English skills \\
\hline & 11 & Thinking about the progress in learning English \\
\hline \multirow[t]{4}{*}{ Affective strategies } & 12 & Trying to relax whenever feeling afraid of using English \\
\hline & 13 & Encouraging to speak English even afraid of making a mistake \\
\hline & 14 & Giving a reward or treat when doing well in English \\
\hline & 15 & Noticing if be tense or nervous when studying or using English \\
\hline \multirow[t]{4}{*}{ Social strategies } & 16 & $\begin{array}{l}\text { If not understanding something in English, asking the other } \\
\text { person to slow down or say it again }\end{array}$ \\
\hline & 17 & Asking English speakers to correct when talking \\
\hline & 18 & Practicing English with other students \\
\hline & 19 & Asking for help from English speakers \\
\hline
\end{tabular}

